Guo, S. \& Yang, Y. (2012). Project-based learning: an effective approach to link teacher professional development and students learning. Journal of Educational Technology Development and Exchange, 5(2), 41-56.

\title{
Project-Based Learning: an Effective Approach to Link Teacher Professional Development and Students Learning
}

\author{
Shaoqing Guo \\ Yanjun Yang \\ Northwest Normal University
}

\begin{abstract}
Professional development for teachers is a key mechanism for improving classroom instruction and student achievement, yet there is little empirical evidence upon which to damonstrate the connection between teachers ' professional development and students' achievement. This paper presents a pilot research which adopts project-based teaching and learning $(P j B L)$ as an approch to link teahcer professional development and student learning. In our longitudinal study, a resource-rich school in urban areas and a less developed school in outlying areas join hands to carry out a research project. Study groups were composed of 2-3 teachers and 10-15 students in each school. The groups from different regions then collaboratively carried out a learning project with the support of an online learning community. The data is collected from focus groups and interviews with stakeholders, online surveys and paper-based questionnaires, computer proficiency tests, observations from site visits, and an analysis of the students' artificial product. Research findings show that project-based collaborative inquiry activity provides the greatest support for teachers and students to develop their comprehensive capacity.
\end{abstract}

Keywords: Project-Based Learning (PjBL), teacher professional development, student achievement

\section{Introduction}

Professional development for teachers is a key mechanism for improving classroom instruction and student achievement (Ball \& Cohen, 1999; Cohen \& Hill, 2000). However, how does teacher professional development affect student achievement? The connection seems intuitive, but demonstrating this is difficult (Yoon, Duncan, Lee, Scarloss, \& Shapley, 2007). It is generally recognized that teacher professional development affects student achievement through three steps. First, professional development enhances teacher knowledge, skills, and motivation. Second, better knowledge, skills, and motivation improve classroom teaching. Third, improved teaching raises student achievement. If one link is weak or missing, better student learning cannot be expected (Yoon, Duncan, Lee, \& Shapley, 2008). Fig.1 illustrates the logical model. In the first step, professional development must be of high quality in its design and implementation. In the second 
step, teachers must have the motivation and skills to apply the professional development to classroom teaching. In the third step, teaching-improved by professional development-raises student achievement. The tremendous challenge is to substantiate the empirical links among professional development, changes in teacher knowledge and skills, changes in classroom teaching, and student achievement. However, relatively little systematic research has been conducted on the effects of professional development on improvements in teaching or in student outcomes (Garet, Porter, Desimone, Birman, \& Yoon, 2001). In a meta-analysis of 93 studies of the effect of teacher development on student performance, Kennedy (1998) reports that only 12 studies show positive effects of staff development. This leads to an evaluation dilemma of teacher professional development in that we know relatively little about what teachers learn from professional development, let alone what students learn as a result of changed teaching practices (Supovitz, 2001).

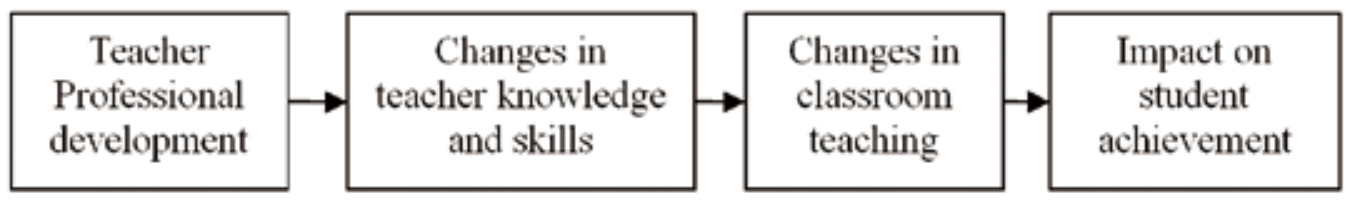

Figure 1. Logical model for how professional development affects student achievement

In order to find a way out of the teacher professional development evaluation dilemma, researchers have followed two major strands of studies. One is claiming rigorous designed research to improve the evidence quality to show the link between professional development and student learning. In a content analysis of more than 1,300 studies identified as potentially addressing the effect of teacher professional development on student achievement, only nine meet the evidence standards (Yoon, Duncan, Lee, \& Shapley, 2008). The results attest to the paucity of rigorous studies and the difficulty of this strategy. The other is restructuring teacher professional development programms to improve the quality of teacher learning. Research on the features of professional development suggests that high quality professional development must immerse participants in inquiry, questioning, and experimentation and, therefore, model inquiry forms of teaching (Supovitz \& Turner 2000).
Specifically, engaging teachers in inquiry about the concrete tasks of teaching, assessment, observation, and reflection, and providing them with the opportunity to make connections between their learning and their classroom instruction is important (Borko, Jacobs, \& Koellner, 2010). Inquiry-based learning (IBL), also known as enquiry-based learning, is a pedagogical approach that uses questioning to involve learners actively in their own learning (Harada \& Yoshina, 2004a). Lots of studies have indicated that IBL is more effective in promoting learning outcomes such as deep thinking, the ability to apply knowledge, and reasoning skills when compared to the traditional didactic approach (Dochy, Segers, Van den Bossche, \& Gijbels, 2003; Harada \& Yoshina, 2004b; Hmelo-Silver, Duncan, \& Chinn, 2007; Hu, Kuh, \& Li, 2008). One way to implement IBL is through student group projects (Chu, 2009; Hmelo-Silver, Duncan, \& Chinn, 2007). Project-Based Learning (PjBL) is aligned with the constructivist framework 
that views learning and teaching as the active and meaningful inquiry and building of knowledge by learners (Sage,2001; Synteta \& Schneiderm2002). According to Prince and Felder (2006), PjBL is defined as: Projectbased learning begins with an assignment to carry out one or more tasks that lead to the production of a final product - a design, a model, a device or a computer simulation. The culmination of the project is normally a written and/or oral report summarizing the procedure used to produce the product and presenting the outcome. In PjBL, learners are engaged in design, problem-solving, decision making, or investigative activities (Kilpatrick, 1918; Land, \& Greene, 2000). This gives students the opportunity to work relatively autonomously over extended periods of time. Numerous studies have shown that $\mathrm{PjBL}$ benefits students in mathematics, science, and reading and English/language arts (Barak \& Dori, 2004; Barab \& Luemand, 2002; Sidman Taveau \& Milner-Bolotin, 2001; Stein, 1995). In PjBL, teacher acts not only as a resource, but also as a guide and a facilitator. They need to move away from their past practice as the usual teacher to a more facilitatory role (Donnelly \& Fitzmaurice, 2005). So, PjBL as a strategy to promote teacher professional development has also been explored and this has turned out to be quite effective (Alastair, 2002; Weizman, Lunderberg \& Koehler, 2007;). An initiative which seeks to determine the effect of project-based learning ( $\mathrm{PjBL}$ ) professional development and implementation on teachers' perceived ability to teach and assess $21 \mathrm{st}$ century skills was launched by the West Virginia Department of Education in 2008. The research results show that teachers who used $\mathrm{PjBL}$ and received extensive professional development reported more teaching and assessment of $21 \mathrm{st}$ century skills overall, with similar patterns seen within subjects and for nearly all of the measured skills (Ravitz, Hixson, English \& Mergendoller, 2012). Kolk
\& Wagner (2012) conducted a research to explore a project-based model for technology professional development. A study on Free Project Based learning show that experiencing FPBL can develop effective content delivery for both teachers and students (Tuncay \& Ekizoglu, 2010).

Can we design a PjBL programm that could benefit both student achievement and teacher professional to cope with the teacher professional development evaluation dilemma? Based on many years study on project-based learning initiatives, we have launched a pilot research project named Telecollaborative Project -based Learning that adopts two strategies: (1) to engage both teachers and students in a project to link teachers professional development and student learning, and (2) to build partnerships between resource-rich schools in provincial/county capital cities and less developed schools in outlying areas to strengthen collaboration. Consequently, this study aims to investigate the effectiveness of Tele-collaborative Projectbased Learning and the research questions are as follows: (1) Can the Tele-collaborative PjBL benefit both student achievement and teacher professional development? and (2) How to optimize the project design to synchronize teacher professional development with student learning?

\section{Methodology}

\subsection{Research Design and Participants}

This initiative was launched by the Beijing office of United Nations Children's Fund and National Centre for Educational Technology, Ministry of Education in May, 2009. The project involves 40 project schools in five counties, namely Tongren counties of Qinghai province, Yuanzhou District of Ningxia Autonomous Region, Yongping county of Yunnan province, Ji'an county of 


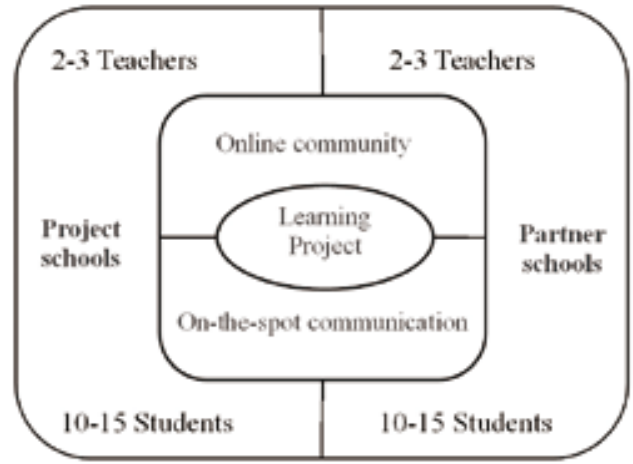

Figure 2. Tele-collaborative project-based learning model

Jiangxi province, and 40 partner schools in five cities (districts), namely Xi'ning city of
Qinghai province, Changzhou city of Jiangsu province, Suzhou city of Jiangsu province, Kunming city of Yunnan province, and Nanchang city of Jiangxi province. Under the support of an online learning community, a study group composed of 2-3 teachers and 10-15 students from a resource-rich school in provincial/county capital cities (named as Partner school) and a study group from a less developed school in outlying areas (named as Project school) joined hands to carry out a research project. See the tele-collaborative project-based learning model in Fig. 2. There are a total of 80 schools, 398 classes, 693 teachers, and 1513 students directly involved in the pilot research. More details are shown in Table 1.

Table 1. Participation Statistics

\begin{tabular}{llll}
\hline $\begin{array}{l}\text { Type of } \\
\text { participation }\end{array}$ & Project counties (districts) & $\begin{array}{l}\text { The number of } \\
\text { participating schools } \\
\text { (schools) }\end{array}$ & $\begin{array}{l}\text { The number of } \\
\text { participating } \\
\text { classes(classes) }\end{array}$ \\
\hline $\begin{array}{l}\text { Schools } \\
\text { involving in } \\
\text { the project }\end{array}$ & Ji'an County & 5 & 93 \\
& Yongping County & 10 & 85 \\
& Tongren County & 5 & 31 \\
& Yuanzhou District & 10 & 30 \\
& Subtotal & 10 & 25 \\
Partner & Nanchang City(Ji'an) & $\mathbf{4 0}$ & $\mathbf{2 6 4}$ \\
& Suzhou City (NingXiaprovince) & 5 & 10 \\
& Changzhou City (Ning Xiaprovince) & 5 & 11 \\
& Kunming (Yulong, Yong ping) & 15 & 13 \\
Total & Xi'ning City (Tongren) & 10 & 33 \\
& Subtotal & $\mathbf{4 0}$ & $\mathbf{6 7}$ \\
& & $\mathbf{8 0}$ & $\mathbf{3 9 8}$ \\
\hline & & &
\end{tabular}




\section{2.Research Procedure}

This research project can be defined as a longitudinal study with mixed-method. Since the project started, the project team has launched a series of activities. The project time line are as follows: (1) complete a project baseline (as a pre-test ), (2) introduce projectbased learning and collaborative learning, (3) practice of project-based learning between rural and urban schools (PjBL), (4) implement WEB2.0 open teaching program, and (5) conduct a final project evaluation (as a posttest ). Table 2 shows the project line.

Table 2. Project Time Line (May, 2009-Dec, 2012)

\begin{tabular}{lllll}
\hline Year & 2009 & 2010 & 2011 & 2012 \\
\hline \multirow{4}{*}{ Interventions } & $\begin{array}{l}\text { Peoject Baseline } \\
\text { (as a pre-test) ;introduce } \\
\text { project-based learning } \\
\text { and collaborative } \\
\text { learning }\end{array}$ & $\begin{array}{l}\text { Tele-collaborative } \\
\text { PjBL Inquery } \\
\text { activitis }\end{array}$ & $\begin{array}{l}\text { WEB2.0 } \\
\text { open teaching } \\
\text { program as } \\
\text { Onle PjBL }\end{array}$ & $\begin{array}{l}\text { Peoject Final } \\
\text { Envaluation } \\
\text { (as a post-test) }\end{array}$ \\
\hline
\end{tabular}

During the whole research period (2009-2012), the project schools and partner schools joined hands to carry out a total of 150 PBL project learning activities of various types. Each school carried out 3-4 projects during the project period. During the PjBL research process, teachers as facilitors were: (1) receiving training from subject experts and teacher PD researchers, (2) determining the Tele-collaborative project and developing research proposal, (3) negotiating research schedules with partnership schools online, (4) and guiding students' inquery activities. Students were: (1) carrying out inquiry activities collaboratively, including desiging, problem-solving, decision making, or investigative activities; (2) sharing research informations, tools and results; and (3) producing a product in the form of VCT.

\subsection{Instrument and Data Collection}

A baseline survey before the experiment and a final evaluation by the end of the experiment was conducted. The data was collected from focus groups and interviews with stakeholders, online surveys and paperbased questionnaires, computer proficiency tests, observations from site visits, and an analysis of the materials developed from the project. Research instruments include: (1) a teacher questionnaire, (2) a student questionnaire, (3) a school master questionnaire, (4) a classroom teaching observation, and (5) a student proficiency test. Computer skills test mainly consists of such five dimensions as Windows operation, text typing, text editing, PowerPoint presentation, and Internet skills, with the total mark of 15 points. The performances of the students' skills in these five dimensions were scored in terms of levels: Skillful (3 points), basic mastery ( 2 points), barely knowing about it (1point), and completely unknown (0 points).

\section{Results and Discussion}

\subsection{Effects on Teacher Professional Development}

The evaluation of effects on teacher's professional development was based on the data which were gathered from 660 teachers' questionnaires, 15 group discussions, 53 teacher interviews, and 18 classroom observations.

\subsubsection{Teachers' Knowledge and Beliefs} Has Been Updated. Through participation in project-based teaching and learning activities, teachers got a new understanding 
of the nature and access of knowledge, of the evaluation of students, and of teachers' role in teaching. Eighty-six point seven percent of teachers involved in the pilot research project have changed their teaching beliefs; $91.4 \%$ of teachers thought they have had a better relationship with students by organizing the exploratory activities; $87.6 \%$ of teachers found that students could do better than they thought before, and they started to trust their students more; and $90.7 \%$ of teachers have tried to get every student to participate actively in their exploratory teaching.

In the focus discussion and interviews, teahcers gave many encouraging comments regarding their project-based teaching and learning experience. Teacher A says, "Our teaching philosophy has changed. It has shifted from focus on lectures of teachers to learning of students, from paying much attention to students' scores to their overall development, and we have a better understanding on how to love our students." Teacher B says, "I can now tolerate the students' mistakes, and I will try to organize some group activities in class and provide more chances for them to show their points of view." Another teacher mentions, "I did not allow students do anything irrelevant to their studies, and they had to follow my words. After participating in the research, I find out that I have to enter their mind, and now I will listen to their advice, and provide chances for them to express their opinion, and allow them to make mistakes, and look at students' mistakes with an open mind."

Through the implementation of the project-based teaching and learning, the educational philosophy of "loving students" grows increasingly prominent in the schools. Teachers are able to treat students fairly by encouraging them. Ninety-four percent of the students say that they are satisfied or very satisfied at the teachers' approaches when they have conflicts with their classmates. Eighty percent indicate that they are encouraged when their performance does not meet the expectations of teachers.

\subsubsection{Change of Teachers' Daily Teaching} Behaviors. A 5-point Likert Scale System based Self-Rating scale was employed to measure the change of teachers' behaviors. Analytic results show that teachers' teaching and practicing ability have been improved by participating in the project-based learning. Compared with the baseline study, when teachers use the downloaded resources in their class (difference 0.37), learning and teaching tools in their class (difference 0.24), attention to the feedback(difference 0.20 ), and organize cooperative learning (difference 0.19) have improved greatly, as shown in Fig.3.

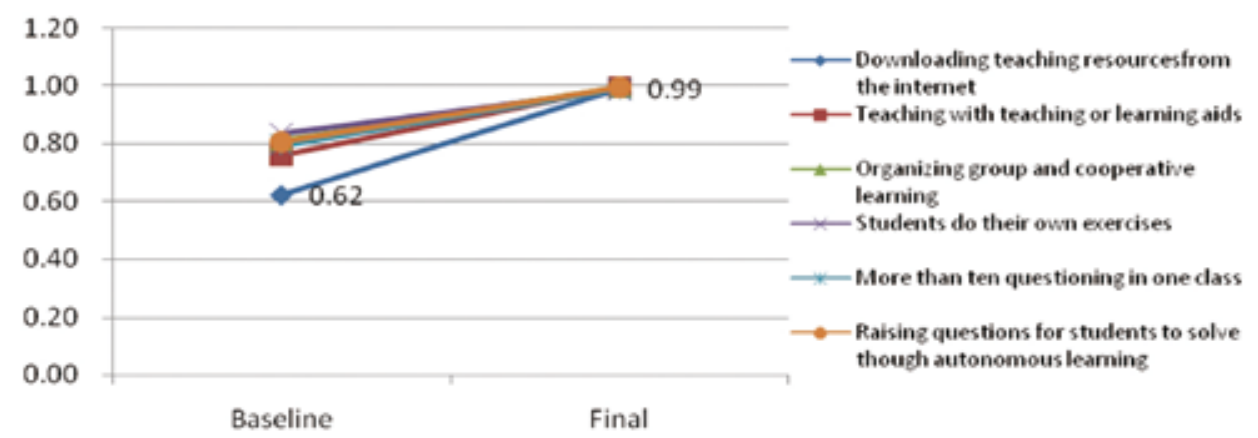

Figure 3. Comparative analysis of teachers' teaching behavior 
In addition, the classroom observation shows that teachers' classroom teaching methods in the following areas have shown marked improvements compared with the baseline survey.

(1) There is a rich variety of sources of teaching content and multimedia technology is widely applied. Teachers pay more attention to the diversity of teaching content source, which is not limited by the textbooks. Compared with the baseline survey, the most obvious change is to use the Internet to download resources for teaching (the difference 0.37), as shown in Fig. 3. In an interview, Teacher Wu says, "In the past, textbook was everything, but now I would share the good articles with students in my class, and in the past, the textbook was the sole duty for a whole semester, but we still find big gap between our students with the others. Now I would introduce all kinds of good methods to my students, or I may feel sorry for them." In addition, the teachers pay more attention to the application of multimedia to show the teaching content; commonly used media such as text and images are shown in Fig. 4. It is noteworthy that students can use the netbook skillfully to help their study in the classroom during our observation. With the interactive software and exploratory resources, the computer has become the tool for students' autonomous research and practice, and the netbook has contributed to the change of students' study method efficiently.

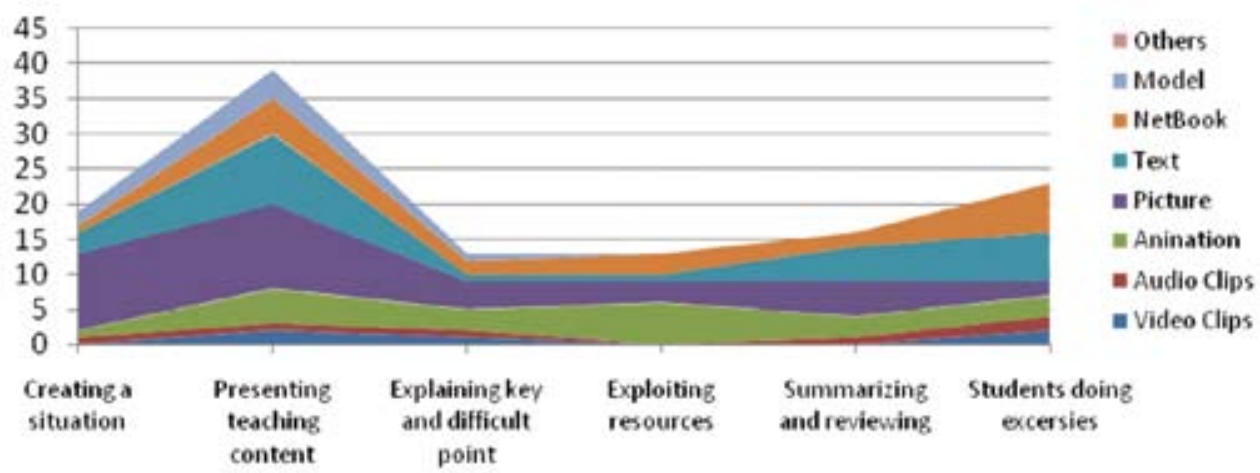

Figure 4. Analysis of teachers' using of multimedia resources

(2) Focusing on group cooperative learning and diversifying activity types. The participation in project-based learning activities has changed the teacher-centered teaching methods, and more attention has been paid to the student group cooperative learning. In the 18 observed classes, teachers organized 3-4 group activities of various forms in each class.
The types of group activities are mainly handson practice $(52 \%)$, cooperative inquiry $(19 \%)$, and discussion and debating (15\%), as shown in Fig. 5. Grouping form of group activities are mainly based on the seat arrangements (52\% are desk mates), or whole-class activities (grouping the students according to their needs, 46\%), as shown in Fig. 6. 


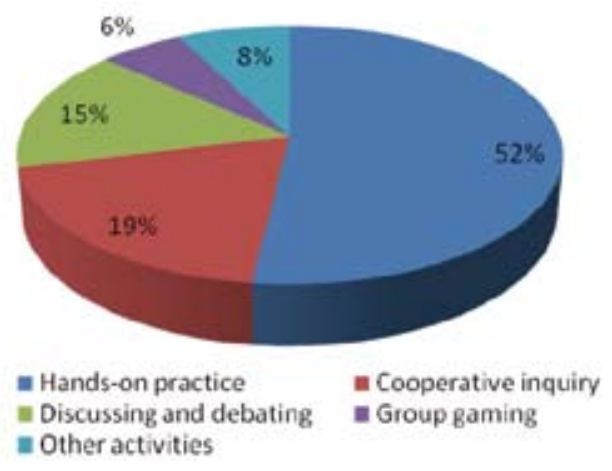

Figure 5. Types of group activities

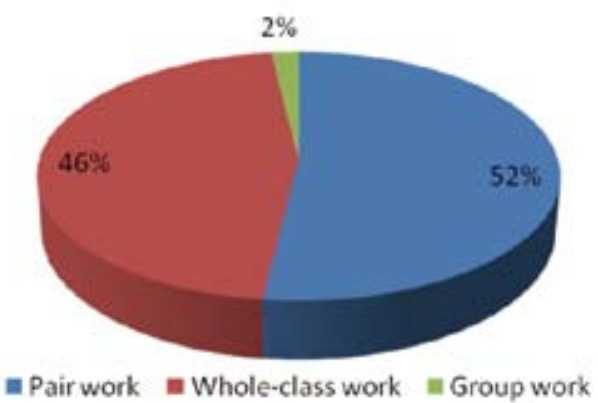

Figure 6. Grouping criteria of activities
Furthermore, $93.06 \%$ of the teachers report that they pay more attention to improving the teaching process. Sixty percent of teachers do the students 'initial-state ability analysis when planning lessons, and $54 \%$ of the teachers in class adjust teaching content according to students' responses. A teacher describes his feelings in an interview as following: "Teachers are changing; we apply the concept of inquiry-based learning to teaching. For instance, when teaching the area of the rectangular, I will use the "jigsaw puzzle "software, ask students to do it themselves, and sum up the formula of rectangular area."

\subsubsection{Teachers' Comprehensive Capacity Has Improved Significantly.}

(1) Teachers' ICT capacity has improved significantly. A 5-point Likert Scale System based questionnaire was employed to measure teachers' ICT capacity. Compared with the baseline survey data, teachers improved their basic computer operations such as Word, Excel, PowerPoint, and their online communication ability, and the difference were $0.269,0.367,0.319,0.375,0.330$ respectively, as shown in Fig. 7.

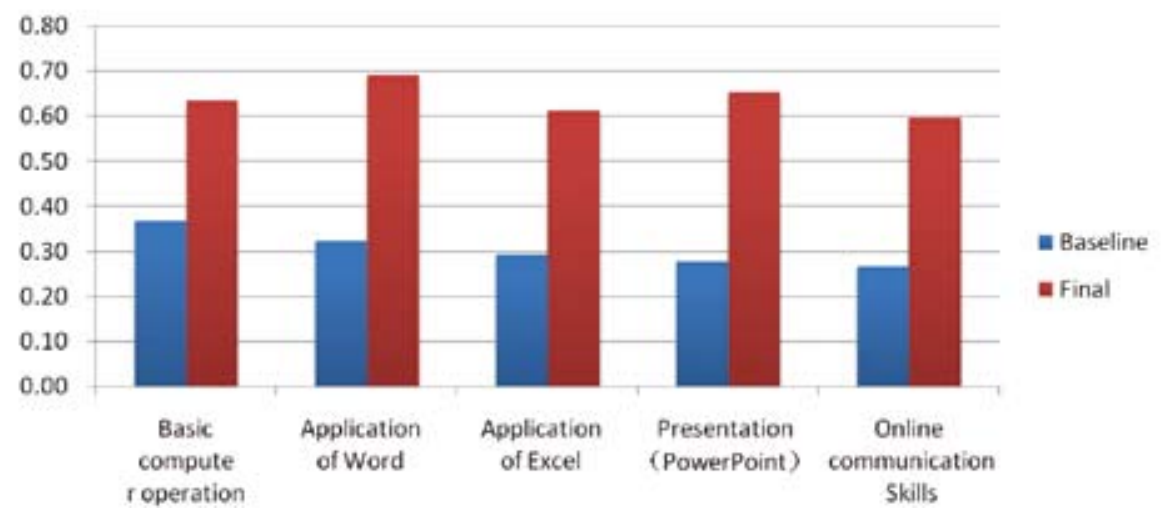

Figure 7. Comparative analyses of teachers' ICT skills 
Eighty-six percent of teachers say that they can skillfully collect and download the required online teaching resources, and $76.7 \%$ of teachers are able to use the online communication tools like blog, BBS, and QQ skillfully. A teacher says, "Before participating in this project, many colleagues and I knew nothing about the computer, even the most basic operation like click and double click, let alone upload and download resources. Since we participated in the project, our ICT capabilities have gradually improved, and even 50-year-old teachers can search the resources online now." He tells us after listening to a class,"The courseware is done by themselves, and the resources are downloaded from the Internet......now I understand the computer is very useful, and it is needed in teaching. So I bought a computer and can surf the Internet at home."

(2) Teachers' organization and management ability as well as team collaboration ability has obviously improved. Through participating in various exploratory activities, $83 \%$ of the teachers think their organization and management ability has been exercised and improved, while $85.7 \%$ of them think their team collaboration initiatives has been strengthened. Eighty-two point seven percent of them think that their team collaboration skill has been improved, and more than $80 \%$ of the teachers begin to communicate with more teachers and promote good practice and experience among colleagues, as shown in Fig.8.

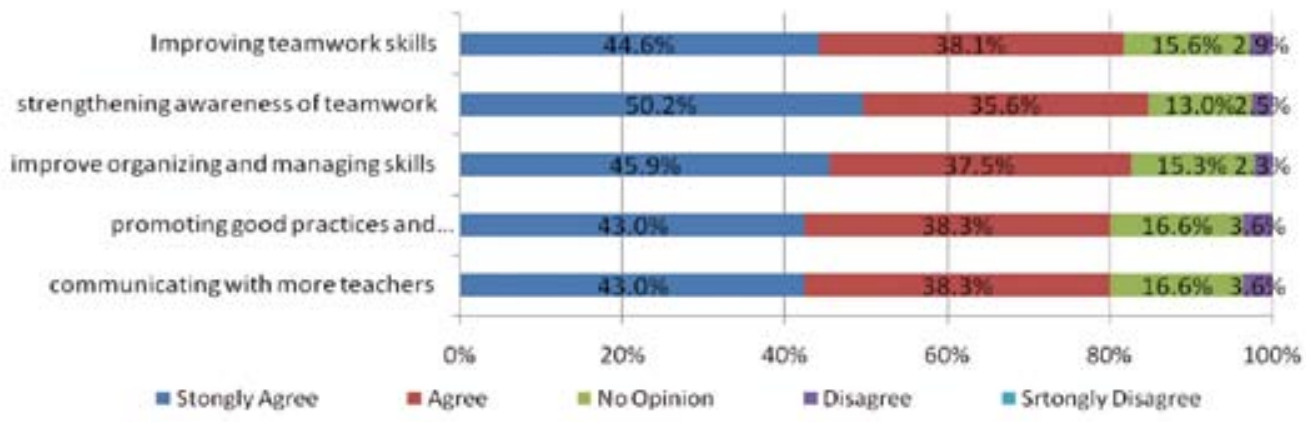

Figure 8 . Teachers' organization and management \& team collaboration ability

(3)Teachers' ability of innovative practice has improved. Through participation in the programms of training of national experts and guiding students to carry out project-based exploratory learning activities, $91 \%$ of the teachers think their vision has been broadened. Eighty-five percent of them gradually try to apply new technologies in teaching, and $87 \%$ of them gradually try new philosophy and methods to change classroom teaching. In an interview, Miss (Mr) Xiao tells us, "I mainly used the software and tools provided by the project in the teaching process, accumulating day by day and month by month. Nowadays,
I can search for some interactive software and tools online by myself."

\subsection{Effects on Students'Achievements}

The evaluation of effects on student' s achievements was based on the data which were gathered from 5162 student questionnaires (including 3649 students who were not directly participating in the research project from non-experimental classes), 175 students computer proficiency tests, 18 classroom observations, and interviews with stakeholders. 
3.2.1. Effects on Students' Attitudes. The questionnaire survey shows that $84 \%$ of the students involved in the project-based learning activities confirmed the great help in improving their confidence; $83.8 \%$ of them think that it was of great help or better help to uphold their learning interests, and $77.7 \%$ of students suggested that they began to like to go to school. Further, $70.8 \%$ of them believe that learning is a very pleasant thing. Being involved in the project-based learning practice, students obtained access to information through more and more diversified channels. They catch more opportunities to communicate with teachers. Seventy-five percent of the students often collected learning materials on the Internet, $76.2 \%$ often participated in group collaborative learning activities, and $75.6 \% \mathrm{t}$ of the students often exchanged with teachers and their classmates when they encountered problems. Students' self-learning ability has been significantly enhanced with about $72.3 \%$ of them independently adjusting their own learning plans, $78.3 \%$ are able to finish the assigned tasks from teachers or students, and $74 \%$ who have completed the teacher assignments are willing to take the initiative to learn other knowledge.

\subsubsection{Students' Knowledge Has Been}

Expanded. Analysis on the theme information of 140 explorative projects shows that students' learning activities based on the project were connected with different disciplines such as mathematics, physics and chemistry, animals, plants, life skills, geography, environment, history, culture, health and hygiene, and so on. The majority of those learning projects involve two or more specific knowledge themes. The multifaceted education acquired by them from those explorative practical activities with the PBL project has greatly enriched students' extracurricular knowledge, and expanded students' knowledge horizon, as shown in Fig. 9.

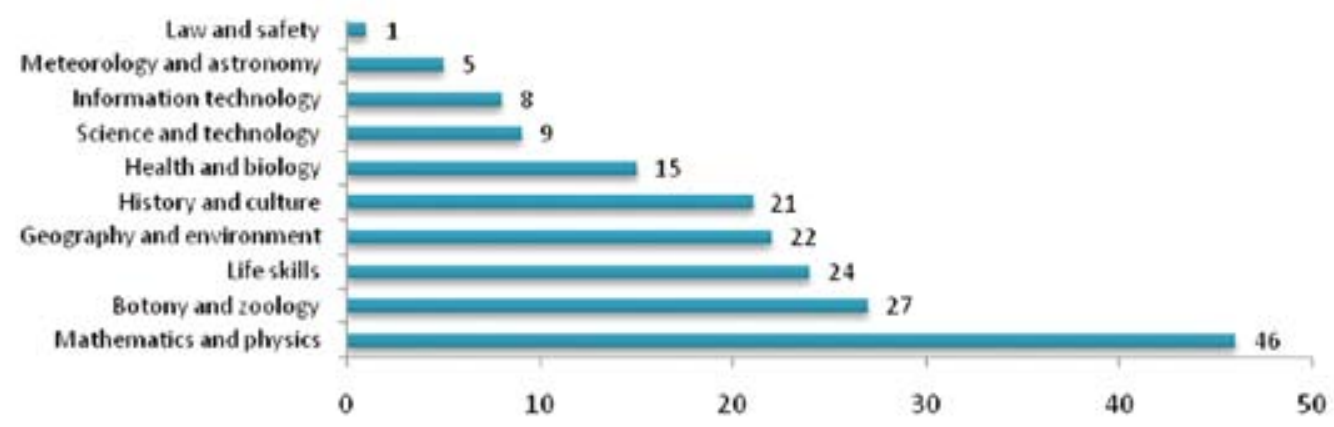

Figure 9. Subject knowledge areas of PBL

\subsubsection{Students' Comprehensive Capacity Has Improved Significantly.}

(1) Students' ICT capacity has been improved significantly. While the project emphasized using ICT as a tool to enhance children's cognitive capacities, it also contributed to improving their computer- use skills. The survey shows that $90.7 \%$ students can operate computers by themselves, $80.3 \%$ can use computers to type, $60.3 \%$ can make digital forms and tables, $62 \%$ can use computers to draw some nice pictures, $73.9 \%$ can talk with friends online proficiently, and $77.3 \%$ can go online to search answer questions they do not understand. 


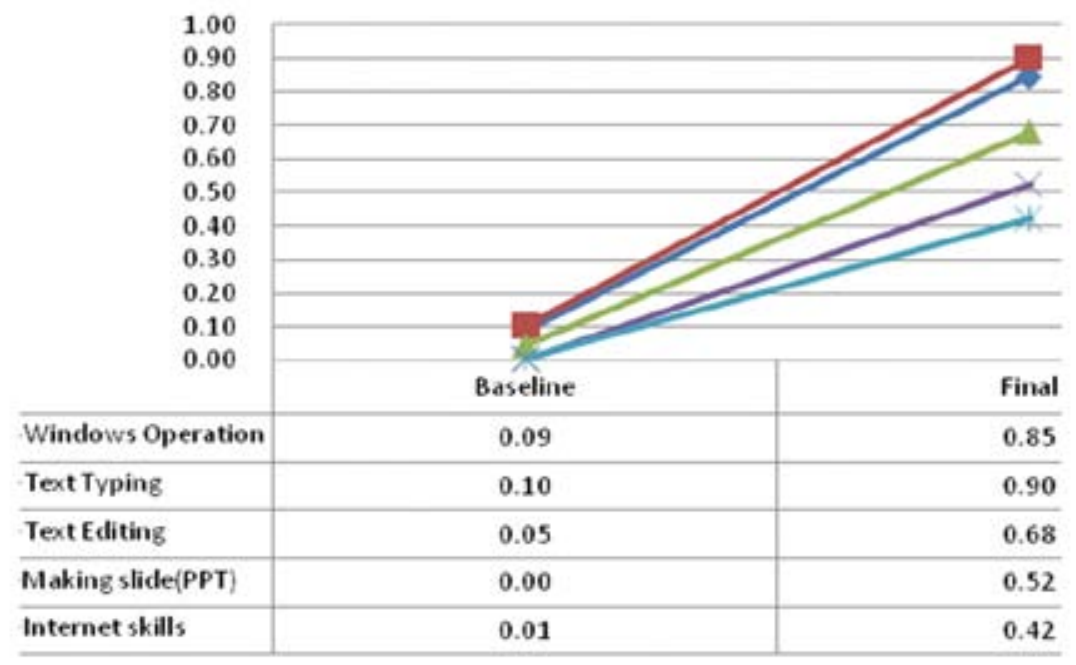

Figure 10. Comparative analysis of students' ICT skill

Based on the student's questionnaire, 175 students receive a computer proficiency test which mainly consists of such five dimensions as Windows operation, text typing, text editing, PowerPoint presentation, and Internet skills, with the total mark of 15 points. The performances of the students' skills in these five dimensions are scored in terms of levels: Skillful (3 points), basic mastery (2 points), barely knowing about it (1point), and completely unknown ( 0 points). There are 102 male and 73 femal students among the 175 students who took the Computer skills test, and they are no older than 12 years in average. In order to be compared with the baseline data, scores are translated into a number no more than one (as an attitude coefficient). Analytic results show that compared with the baseline survey data, students' abilities related to the use of Windows system, text typing, file editing, PowerPoint making, and Internet operations, etc. have been greatly improved. As shown in Fig. 10.
(2) Students' group cooperation capacity has been improved significantly. A 5-point Likert Scale System based questionnaire was employed to measure students' group cooperation capacity. The results show that students' sense of cooperation and cooperative skills have been significantly strengthened. Respectively, $76.7 \%$ and $68.5 \%$ of students think they can learn a lot and obtain more resources by collaborating with others. Seventy-one point seven percent are willing to speak their own ideas in public, and $68.4 \%$ are willing to share resources with others. Fiftyeight point eight percent are able to accurately express their ideas, $56 \%$ can summarize group presentations, and $67.5 \%$ say that they may patiently listen to others when they disagree with others' views. Further analysis reveals that students who are actually involved in the project graded higher than those who just "understand" or "do not know" in all aspects of the evaluation about group cooperative learning, as shown in Fig. 11. 


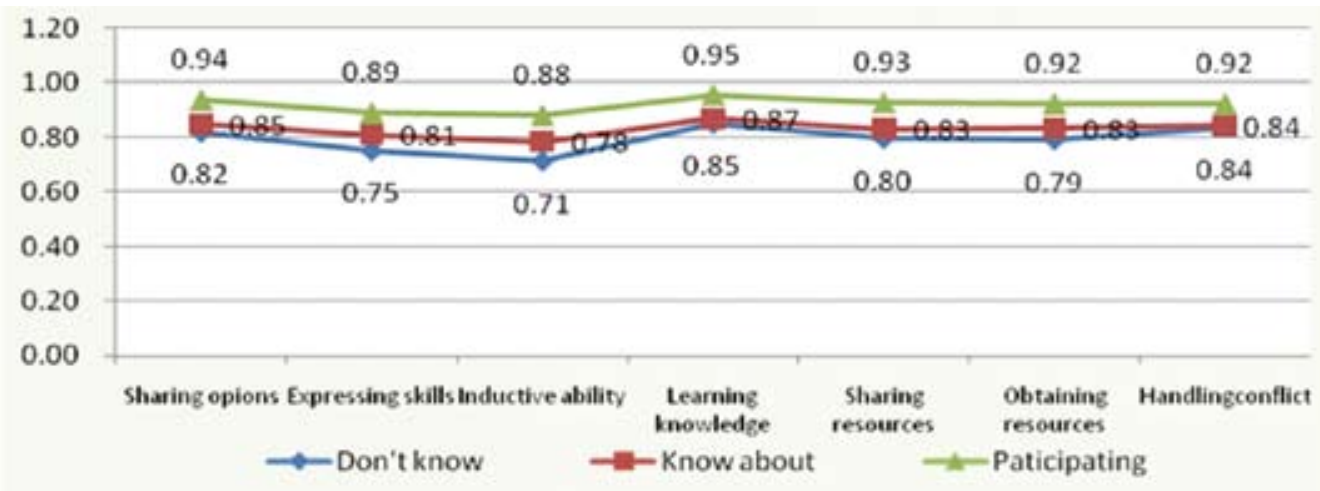

Figure 11. Students' group cooperation capocity

(3) Students' independent research capacity has been improved significantly. A 5-point Likert Scale System based questionnaire was also employed to measure students' independent research capacity. With the implementation of the project, students' abilities to identify, ask, and solve problems have been strengthened. Fifty-one point four percent of the students say that they are able to think differently in daily learning and life, $53.3 \%$ are able to put forward a variety of solutions to problems, and $64.4 \%$ can often reflect on the things they did. Further analysis reveals that students who are actually involved in the project graded higher than those who just "understand" or "do not know" in all aspects of the evaluation about autonomous research learning, as shown in Fig. 12. During a field exchange visiting process between the a rual school and an urban school, some students found that students from the urban school are generally taller and stronger than the students from the rural school while watching the pictures they have. They raise the question of whether children in cities are fatter than children in rural areas. After serious thinking, the two sides established a collaborative inquiry project on "Diet and Health." They explored reasons for the issue through surveys on the diet of both sides and gave an analysis of the major food nutrients

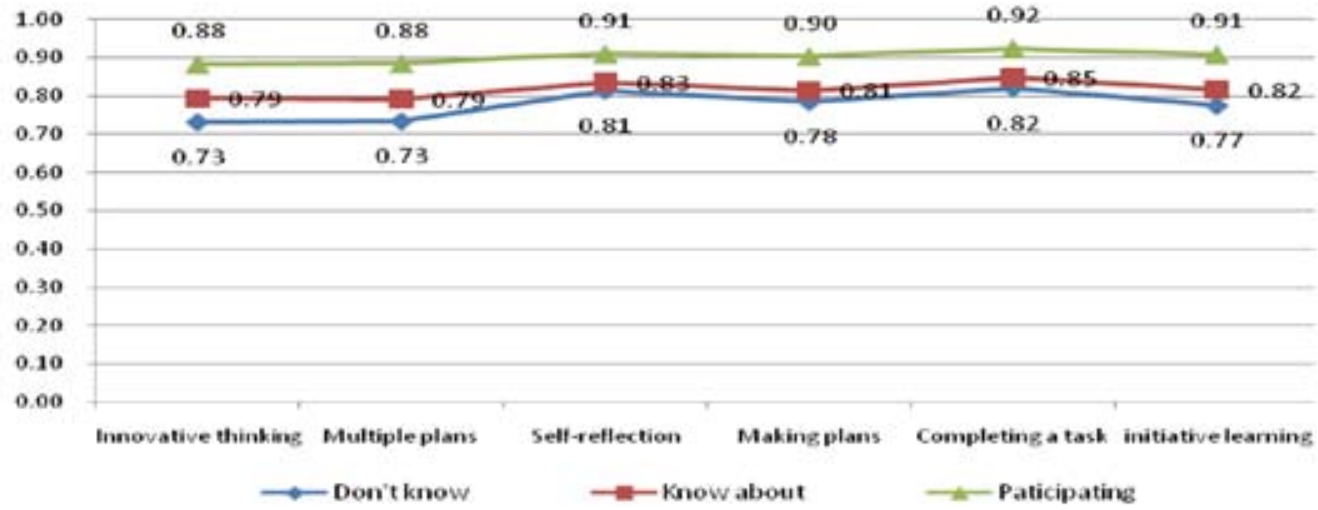

Figure 12. Analysis of students' independent research capacity 


\section{Conclusions}

PBL collaborative inquiry activity provides the greatest support for teachers and students to develop their comprehensive capacity. For the teachers, their classroom behavior and daily teaching activities, together with ICT capabilities, organizational management, and team collaboration capabilities, and innovation and practical ability have been significantly improved through the participation in the projectbased teaching and learning activities. For the students, their ICT capabilities, group cooperation capacities, capacity for problem identifying, and problem solving all have grown and thrived. Further investigations on self-assessment reveals that students who are actually involved in the project at different levels perform better than those who just "understand" or "do not know" in all aspects of the evaluation about computer operation, access to learning materials, solutions for problems, online communication, group learning, self-independence, and observing sensibility. It can be seen that the project practice has an important influence on the development of students' comprehensive abilities. Practice of PBL collaborative research has become the main support for the development of teachers and students' comprehensive ability. Project-Based learning (PBL) can be used as an effective approach to link the teacher professional development and student achievement.

\section{References}

Alastair, D. M. (2002).Problem-based learning in initial teacher education: taking the agenda forward. Journal of Educational Enquiry, 3(1), 60-78.

Ball, D. L., \& Cohen, D. K. (1999). Developing practices, developing practitioners: Toward a practice-based theory of professional development. In G. Sykes \& L. Darling-Hammonds (Eds.), Teaching as the learning profession: Handbook of policy and practice (pp. 30-32). San Francisco, CA: Jossey-Bass.

Barab, S. A., \& Luehmann, A. L. (2002). Building sustainable science curriculum: acknowledging and accommodating local adaptation. Science Education, 87(4), 454-467.

Barak, M., \& Dori, Y. J. (2004). Enhancing undergraduate student's chemistry understanding through project based learning in an IT environment. Science Education, 89(1), 117-149.

Borko, H., Jacobs, J., \& Koellner, K. (2010). Contemporary approaches to teacher professional development. In P. Peterson, E. Baker, \& B. McGaw (Eds.), International encyclopedia of education (Vol. 7, pp. 548-556). Oxford, England: Elsevier.

Chu, S. (2009). Inquiry project-based learning with a partnership of three types of teachers and the school librarian. Journal of the American Society for Information Science and Technology, 60, 1671-1686.

Cohen, D. K., \& Hill, H. C. (2000). Instructional policy and classroom performance: The mathematics reform in California. Teachers College Record, 102(2), 294-343.

Donnelly, R., \& Fitzmaurice, M. (2005). Collaborative Project-based Learning and Problem-based Learning in Higher Education: A Consideration of Learnerfocused Strategies. In G. O'Neill, S. Moore \& B. McMullin (Eds.) Emerging Issues in the Practice of University Learning and Teaching (pp. 87-98). Dublin: AISHE/HEA.

Dochy, F., Segers, M., Van den Bossche, P., \& Gijbels, D. (2003). Effects of problembased learning: a meta-analysis. Learning and Instruction, 13, 533-568. 
Garet, M. S., Porter, A. C., Desimone, L., Birman, B. F., \&Yoon, K. S. (2001). What makes professional development effective? Results from a national sample of teachers. American Educational Research Journal, 38(4), 915-945.

Harada, V. H., \& Yoshina, J. M. (2004a). Inquiry learning through librarianteacher partnerships. Worthington, $\mathrm{OH}$ : Linworth Publishing.

Harada, V. H., \& Yoshina, J. M. (2004b). Moving from rote to inquiry: Creating learning that counts. Library Media Connection, 23, 22-24.

Hmelo-Silver, C. E., Duncan, R. G., \& Chinn, C. A. (2007). Scaffolding and achievement in problem-based and inquiry learning: a response to Kirschner, Sweller, and Clark (2006). Educational Psychologist, 42, 99-107.

Hu, S., Kuh, G., \& Li, S. (2008). The effects of engagement in inquiry-oriented activities on student learning and personal development. Innovative Higher Education, 33, 71-81.

Kilpatrick, W. H. (1918). The project method. Teachers College Record, 19(4), 319-335. Kennedy, M. (1998). Form and substance in in-service teacher education. Madison. National Institute for Science Education, University of Wisconsin-Madison.

Kolk,N.,\& Wagner, D.(2010).A Project-Based Approach to Professional Development. Retrived from: http://creativeeducator. tech4learning.com/main/articles pd

Land, S. M., \& Greene, B. A. (2000). Projectbased learning with the World Wide Web: a qualitative study of resource integration. Educational Technology Research and Development, 48(1), 45-66.

Prince, M. J., \& Felder, R. M. (2006). Inductive Teaching And Learning Methods: Definitions, Comparisons and Research Bases . Journal of Engineering. Education, 95(2), 123-138
Ravitz, J., Hixson, N., English, M., \& Mergendoller, J. (2012). Using project based learning to teach 21 st century skills: Findings from a statewide initiative. Paper presented at Annual Meetings of the American Educational Research Association. Vancouver, BC.

Tuncay,N., \& Ekizoglu, N. (2010).Bridging achievement gaps by "free" project based learning. Procedia Social and Behavioral Sciences, 2, 5664-5669.

Supovitz, J.A., \& Turner, H.M. (2000). The effects of Professional Development on Science teaching practicies and classroom culture. Journalof Research in Science teaching, 37, 963-980.

Supovitz, J. A. (2001). Translating teaching practice into improved student performance. In S. H. Fuhrman (Ed.), From the Capitol to the Classroom: Standards-based Reform in the States. 100th Yearbook of the National Society for the Study of Education, Part II (pp. 8198). Chicago, IL: University of Chicago Press.

Sage, S. (2001).Using Problem Based Learning to teach Problem-Based Learning. In B.B. Levin (Ed.), Energizing teacher education with professional development with problem-based learning (pp. 87-107). Alexandra, VA: Association for Supervision and Curriculum Development.

Synteta, P., \& Schneider, D. (2002). EVA pm: how XML can scaffold project-based learning. Proceeding of the 4th international conference on new educational environments (ICNEE'02), Lugano, Switzerland.

Sidman-Taveau, R., \& Milner-Bolotin, M. (2001). Constructivist inspiration: A project-based model for L2 learning in virtual worlds. Retrieved from : http://eric.ed.gov/ERICDocs/ data/ericdocs 2 sql/content_storage_01/ 0000019b/80/29/cf/ae.pdf 
Stein, S. (1995). Equipped for the future: A customer-driven vision for adult literacy and lifelong learning. Washington, DC: National Institute for Literacy.

Tuncay, N., \& Ekizoglu, N.(2010).Bridging achievement gaps by "free" project based learning. Procedia Social and Behavioral Sciences, 2,5664-5669.

Weizman, A., Lundeberg, M.A.,\& Koehler, M.J.(2007).The Influence of Problem Based Learning Professional Development on Science Teachers' Pedagogical Content Knowledge. Paper Presented at the 2007 European Science Education Research Association. International Conference.

Yoon, K. S., Duncan, T., Lee, S. W.-Y., Scarloss, B., \& Shapley, K. (2007). Reviewing the evidence on how teacher professional development affects student achievement (Issues \& Answers Report, REL 2007-No. 033). Washington, DC: U.S. Department of Education, Institute of Education Sciences, National Center for Education Evaluation and Regional Assistance, Regional Educational Laboratory Southwest. Retrieved from http://ies.ed.gov/ncee/edlabs

Yoon, K.S., Duncan, T., Lee, S. \& Shapley, K. (2008). The effects of teachers' professional development on student achievement: Findings from a systematic review of evidence. Presented at the Annual Meeting of the American Educational Research Association.New York, NY. 


\section{Contact the Authors}

\section{Shaoqing Guo}

Northwest Normal University

Email: guosq1995@163.com

\section{Yanjun Yang}

Northwest Normal University

Email: ts.yyj@126.com 